\title{
DIREITO, JUSTIÇA E MITO: UMA LEITURA A PARTIR DE O PROCESSO, DE F. KAFKA
}

\author{
Daniel Yamauchi Acosta ${ }^{1}$ \\ RUTH FARIA DA COSTA CASTANHA ${ }^{2}$
}

\begin{abstract}
RESUMO: O presente estudo tem como objetivo discutir a importância da literatura ao estudo do direito, sob a ótica da obra $O$ processo, de Franz Kafka. Este artigo procura investigar a forma sob a qual a poesia e o mito podem ser utilizados para uma reflexão acerca dos problemas vivenciados tanto pelos operadores do direito quanto por aqueles que, independentemente de sua vontade, ficam sujeitos à angústia causada pelos morosos e burocráticos processos judiciais isso na melhor das hipóteses, quando não infligindo marcas sociais indeléveis que passam a acompanhar o indivíduo pelo resto de suas vidas. Ainda nesse escopo, o estudo pretende perquirir a relatividade do conceito de justiça como uma das causas relacionadas à estagnação do direito enquanto ciência jurídica.
\end{abstract}

Palavras-chave: direito; esquecimento; justiça; mito; Franz Kafka.

\section{INTRODUÇÃO}

Segundo Paulo Ferreira da Cunha (2005, p. 33), o direito deve ser visto sob tríplice perspectiva: técnica, ciência e arte. A técnica e a ciência servem à arte, e é na literatura em que esta se manifesta: por meio da leitura do humano, partindo-se da ficção e da poética - seja por meio da utopia em que o direito se insere, seja pelo cunho mítico igualmente contido na magia das letras. Tal como na literatura, o direito possui suas personagens, com papéis predeterminados e figurinos próprios, contidas em um enredo específico. Em ambos os campos do conhecimento, os

1 Mestrando em Filosofia e Teoria Geral do Direito na Pontifícia Universidade Católica de São Paulo (PUCSP). Bolsista da CAPES. São Paulo, SP. CV Lattes: <http://lattes.cnpq.br/0312771166339915>. E-mail: dyacosta@uol.com.br.

2 Mestranda em Filosofia e Teoria Geral do Direito na Pontifícia Universidade Católica de São Paulo (PUCSP). Bolsista da CAPES. São Paulo, SP. CV Lattes: < http://lattes.cnpq.br/1867000984565674>. E-mail: ruthfariacastanha@gmail.com. 
protagonistas estão predestinados à história de seus escritores, eis que o operador da lei tem a sua atuação delimitada pela interpretação das Cortes judiciárias. O direito, como arte que é, possui pessoalidade própria: a sua real compreensão toma dimensão sob os olhares de outrem, em uma complexa dinâmica de interpretações normativas. Cada sentença judicial é a expressão da trajetória de um indivíduo, cada decisão imposta estampa uma imagem - por vezes transitória, mas geralmente inextinguível - na vida de um homem. Todo e cada caso é uma experiência única, na medida em que o sujeito é um texto vivo, interpretado desde si mesmo - e, tal como o poema, deve ser compreendido a partir da percepção do leitor. Ora, se o ponto de partida para a interpretação do direito provém daquele que o opera (um indivíduo que, tal como todos, percebe a vida segundo suas próprias experiências e valores) torna-se evidente o sutil liame existente entre o direito e a arte.

Assim, a partir dessa compreensão, percebe-se a importância da literatura para fins de compreensão da realidade. Para os termos deste artigo, propomos um diálogo entre a consagrada obra $O$ processo, de Franz Kafka, e a prática jurídica produzida pelo direito positivo - uma realidade frequentemente norteada ora pelo esvaziamento, ora pela supervalorização do ideal de justiça como valor fundamental do sistema. Como consequência dessa análise e considerando-se ainda os princípios constitucionais da publicidade e da livre manifestação do pensamento, em uma sociedade moderna alimentada pela internet e suas redes sociais, há de se traçar alguns comentários sobre a necessidade de se garantir o direito ao esquecimento, algo do qual pouco se comenta nos círculos acadêmicos (não nas dimensões que a abordagem adequada da questão demandaria, ao menos), muito embora trate-se de assunto que transcenda a esfera dos direitos e opere profundas consequências socioeconômicas na vida dos acusados e/ou condenados pelo sistema (independentemente de juízos de justiça ou merecimento), pessoas cujas trajetórias de vida tornam-se irremediavelmente marcadas pela publicidade dos atos processuais.

Cabe explicitar, ainda, que, na redação deste artigo, os autores se valeram da pesquisa bibliográfica (critério quantitativo) aplicando a metodologia dedutiva. A pesquisa compreendeu algumas fases: a escolha do tema, elaboração do plano de trabalho, identificação, localização, 
compilação, análise, interpretação e redação (Lakatos e Marconi, 2003, p. 44). No desenvolvimento do estudo, procurou-se trazer respostas às questões mais inquietantes do direito: a subjetividade do conceito de justiça e o funcionamento ideal do sistema Judiciário. A transversalidade e o diálogo com outros ramos do conhecimento foram essenciais, dada a profusão das mais diversas celeumas jurídicas que envolvem a questão. A análise toma como referência inicial a literatura de Franz Kafka, a partir da qual busca-se compreender o humano, suas misérias e temores, razão pela qual se optou por um tratamento analítico eminentemente estético.

\section{DIREITO E LITERATURA: UM PONTO DE PARTIDA NECESSÁRIO}

Em que pesem opiniões em contrário, o fato é que o direito possui profunda carga de subjetividade. O diálogo proposto entre as ciências jurídicas e a literatura é ferramenta indispensável à compreensão de valores jurídicos que, embora objetivamente estabelecidos segundo a sistemática positivista, possuem uma dinâmica eminentemente hermenêutica. Dentre as diversas literaturas que despontaram ao longo dos últimos dois séculos sobre o tema, as dramáticas narrativas kafkianas estão, reconhecidamente, dentre as que, quase em tom profético, anteciparam a hipocrisia dos Estados totalitários do séc. XX e de seus sistemas jurídicos: alegando impessoalidade, destruía-se a individualidade; invocando a ordem, promovia-se a arbitrariedade; afirmando eficiência, praticava-se o descaso. Não que isso não ocorresse antes, sob a égide das grandes monarquias europeias, mas, de certa forma, na medida em que a ideologia então adotada era manifestamente absolutista (tal como aquela defendida por Maquiavel e Hobbes), as regras eram francamente mais claras. Com a Revolução Francesa e a consagração de valores que a partir de então passaram a moldar as estruturas políticas ocidentais, as águas do direito tornaram-se "turvas". Diversos ordenamentos jurídicos foram organizados sobre os pilares soberanos da vida, da liberdade, da igualdade, da justiça e da propriedade privada - ao menos na aparência. Na prática, contudo, promoveu-se aquilo que denominamos "desprezo juridicamente qualificado": a assombrosa sistematização do descaso pela condição humana, por meio do processo - supostamente o instrumento jurídico que promoveria a observância de direitos individuais no plano material -, segundo a perversa 
ironia de se justificar a despersonalização do sujeito sob a égide do princípio da igualdade (conferindo-se, de fato, um tratamento igualmente aterrorizante a todos aqueles que tivessem a infelicidade de se tornarem alvos do sistema, pelo motivo que fosse). Dito isso, passamos então a analisar o retrato assombrosamente verossímil dessa realidade jurídica estampada na obra de Kafka.

\subsection{Kafka e a literatura: uma leitura do homem e da subjetividade}

Consagrado como um dos precursores modernos do existencialismo, Franz Kafka nasceu no ano de 1883, em Praga, atual República Tcheca, vindo a falecer em 1924, um mês antes de completar 41 anos, próximo à cidade de Viena, na Áustria. Advindo de uma família de origens judaicas, abandonou o curso de química para estudar direito, graduando-se em 1906 e obtendo, assim, o título de Doutor em Leis. No entanto, nutrindo gosto pela arte e sob a influência de autores como Dostoiévski, dedicou-se com afinco à literatura. Sua principal obra, O processo, foi iniciada em 1914 e teve sua produção interrompida algumas vezes. Em verdade, Kafka jamais daria a obra por acabada; os escritos originais foram entregues ao seu amigo Max Brod, a quem pedira que os queimasse após a sua morte (e Brod lhe respondeu que não o faria). A primeira publicação ocorreu em 1925, um ano após a tuberculose finalmente vencer-lhe as forças. Considerado um dos maiores romances do século $\mathrm{XX}, \mathrm{O}$ processo retrata formidavelmente as vicissitudes das estruturas jurídicas: desde a cúpula do Poder Judiciário aos servidores de menor hierarquia, Kafka traça uma magistral caricatura do sistema, suas instituições e seus protagonistas, demonstrando a hipocrisia do próprio discurso jurídico da qual se apropria uma justiça decadente e insana.

Na obra, Josef K., um bem-sucedido funcionário de banco, tem a sua rotina repentinamente interrompida pela visita de agentes do Estado, que o declaram detido. No entanto, ninguém é capaz de lhe apresentar qualquer justificativa que autorize o procedimento. K. não obtém qualquer resposta quanto à acusação - cujo teor não se conhecerá em momento algum, ao longo de toda a obra. Naquele instante, Josef passa a questionar sua realidade: "A que autoridade pertenciam? K. ainda vivia numa Estado de Direito, reinava paz em toda parte, todas as leis estavam em vigor, quem 
usava cair de assalto sobre ele em sua casa?” (Kafka, 2007, p. 13). A estabilidade e a segurança em que se fundava a vida de $\mathrm{K}$. lhe foram abruptamente tolhidas, em nome da aplicação da lei (a partir de então, K. jamais viria a recobrar a sua paz de espírito). Percebe-se assim, ab initio, uma nítida contradição entre o sentido originário da norma e a ação arbitrária do Estado.

A obra kafkiana revela a vulnerabilidade do homem frente às instituições por ele mesmo criadas. K. era, notoriamente, um cidadão de bem, sem crime ou culpa aparentes, mas que fora detido sob a égide de um complicado processo judicial, cujos julgadores eram figuras desconhecidas e inalcançáveis dentro de um mundo de infindáveis burocracias, e por uma acusação que jamais lhe é revelada - tudo formalmente legitimado, segundo a sistemática jurídica vigente.

Discutem-se, por diversas vezes, preceitos e valores que, transcendendo muito além do universo jurídico, compõem o sentimento mais básico de justiça do ser humano (a justiça, na qualidade de valor juridicamente consagrado, é, conforme mencionado, algo muito mais subjetivo do que se aparenta) ${ }^{3}$. A literatura tem uma linguagem que lhe própria: explica-se o indivíduo sob uma análise externa, capaz de denunciar as mazelas e as misérias humanas por meio do relato (seja real ou fictício, em tom descritivo ou onírico), uma forma eficiente de se estabelecer o diálogo com o leitor, levando-o a ponderar os limites da subjetividade e da existência humana. Conforme definição encontrada no Dicionário de filosofia, define-se a subjetividade como o "caráter de todos os fenômenos psíquicos enquanto fenômenos de consciência, que o sujeito relaciona consigo mesmo e os chama de meus" (Abbagnano, 2007, p. 922). A subjetividade é, de certa forma, a manifestação da liberdade que se opera no interior do homem, consubstanciada na possibilidade de realizar escolhas ${ }^{4}$. Trata-se de conceito diretamente ligado à formação da identidade, que se traduz a partir do espaço íntimo do indivíduo e de suas experiências (intersubjetividade). Para Sören Kierkegaard, teólogo e

3 Não por acaso, Hans Kelsen dedicou diversas obras sobre o tema ( $O$ que é justiça?, $A$ ilusão da justiça, O problema da justiça, apenas para mencionar algumas).

4 Vale lembrar que a subjetividade também abarca a concepção de inconsciente formulada por Sigmund Freud. 
filósofo dinamarquês do século XIX, a subjetividade consiste em uma experiência de reapropriação do $E u$ - em outras palavras, não se trata de um processo mental arbitrário ou irracional. Há menções no Post-scriptum atestando, inclusive, que "a subjetividade é a verdade". Ou seja, somente o indivíduo existente e que se assume enquanto tal pode reapropriar-se da sua subjetividade. Assim, a literatura é capaz de realizar a intersecção desses mundos (interior/exterior), ao promover o encontro do homem com o seu Eu. Para o professor Roberto Bueno, a "literatura é um instrumento promissor, provavelmente mais do que a filosofia, quando temos em perspectiva um processo de autorreferenciação" (2011, p. 10), compreendido como um processo de autodefinição e reconstrução de nós mesmos, dada a historicidade humana.

A narrativa de Kafka revela a angustiante busca de Josef K. pelo teor da acusação que lhe fora imputada. O romance cativa o leitor pelos relatos da agonizante marcha processual iniciada a pretexto de uma acusação aparentemente infundada, da qual jamais se conhece o conteúdo (de cunho presumivelmente criminal, mas que jamais fica claro), e a obra foca-se sobre a torturante busca de $\mathrm{K}$. por respostas. A indignação de Josef (às vezes traduzida em altivez, em certas passagens) é contraposta à postura resignada dos demais acusados em outros processos (outras personagens com quem K. passa a ter contato ao longo da narrativa). Há aqui uma discussão em torno das diferentes posturas adotadas pelo indivíduo frente ao mundo, seja esse o real 5 ou o fenomênico. A coisificação do $E u$ pelas instituições burocráticas também é tema de aprofundamento na obra, isto é, algo perceptível em todos os personagens apresentados. Nota-se que todo o sistema contribui para o completo esvaziamento da pessoalidade. Kafka, que desprezava a psicologia, traça, ao longo de toda a sua obra, intuições psicológicas que amarram os protagonistas uns aos outros. O processo não é tão-somente uma crítica social: ele relata a miséria inerente ao homem e a frieza decorrente do distanciamento de sua própria interioridade. A obra remete o leitor à reflexão sobre aquilo que realmente somos e quais valores efetivamente preconizamos. Enfim, Kafka transmite a ideia da necessidade de se (re)pensar as relações humanas e a forma como somos absorvidos

5 Ou numênico, segundo a nomenclatura adotada por Immanuel Kant. 
pela indiferença dos procedimentos judicialmente mecanizados que, sob o tradicional pretexto da pacificação e harmonização das relações sociais, apenas se prestam, afinal, a destruir a individualidade.

\subsection{O salto do direito para a poética e o abandono do profetismojurídico}

A expressão saber poético - embora remeta, inicialmente, à ideia diversa - traduz, por assim dizer, uma realidade nua. A literatura não se presta à prescrição desmedida e irrestrita de um suposto mundo do deverser, desconectado do mundo real - muito pelo contrário, os mitos perpetuam-se ao longo da história dos povos justamente porque abordam temas permanentemente contemporâneos, relacionados à condição humana. O direito, por sua vez, tem por tradição teórica apontar os rumos do comportamento social por meio da imposição de normas gerais, um ramo que, não raramente, dissocia-se da realidade em que se insere. A poética não se contrapõe à ciência jurídica - ao invés disso, lhe confere uma compreensão mais aproximada da realidade por meio da estética ${ }^{6}$. Ressaltese que não se defende, aqui, o abandono da análise do porvir e a necessidade de mudanças por meio da lei. Entretanto, o direito, como fenômeno social, é também fruto da história e dos costumes de um povo, de forma que o seu ponto de referência encontra-se sempre no passado. Por outro lado, a fim de se induzir a comportamentos socialmente desejados, é imprescindível que a lei se baseie o máximo possível nos valores atuais, consagrados no presente, pela sociedade. Assim, o sistema jurídico promove um salto quando se vale da poética para encontrar o seu lugar no tempo.

O movimento Direito e Literatura (Law and Literature) nasceu nos EUA, no início do século XX, e posteriormente se estabeleceu na Europa, chegando, em sua última fase, aos países latino-americanos (Ost, 2006, p. 334). É importante diferenciar-se as três perspectivas da relação entre o direito e a literatura: (a) o direito $d a$ literatura, com foco na garantia da liberdade de expressão e estudo da história jurídica da censura; (b) o direito como literatura, voltada ao estudo da retórica e de textos jurídicos; e (c) o direito na literatura, que busca nos textos literários (e não nos textos

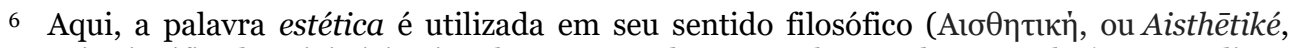
cujo significado originário vincula-se ao ato de se perceber ou de notar algo), na condição de reflexão crítica da cultura e natureza humanas. 
jurídicos, manuais ou cursos) o direito, a justiça e o poder (Ost, 2006, p. 334). O estudo dos textos de Kafka está localizado no âmbito do direito na literatura. A partir do romance, ora objeto de investigação, busca-se debater as contradições do direito enquanto ciência.

O positivismo do século XIX, calcado no racionalismo cientificista da época, tentou atribuir, a tudo que lhe fosse submetido para análise, um sentido fulcrado na razão - despido, portanto, de concepções estéticas que indicassem qualquer lastro de "sentimento". Houve uma espécie de esquecimento e de "demonização" da poética, algo então julgado como necessário ao aprofundamento da reflexão humana, causando, assim, o abandono pela busca de um olhar refinado do mundo pelos olhos da linguagem. Contudo, a teoria jurídica desenvolvida ao longo dos séculos XVIII, XIX e XX não responde às demandas da atualidade; os modelos e esquemas concebidos durante o movimento racionalista não são mais capazes de atender às complexidades da sociedade hodierna. As relações de poder se fragmentaram, e a concepção do que é político não orbita mais exclusivamente ao redor do Estado, a exemplo da criação das instituições de terceiro setor. No ponto, outro exemplo relevante é a criação do instituto da arbitragem, instrumento que vem despontando com boa aderência pelas empresas, demonstrando-se, assim, uma clara ruptura da concepção de exclusividade do Judiciário para a resolução de conflitos.

Diante da crescente complexidade social, as ciências jurídicas passaram por um processo de reestruturação em suas instituições seculares7. Ante essa nova realidade, a reformulação do conceito de política levou à superação das estruturas jurídicas até então vigentes ${ }^{8}$. A fim de se adequar às expectativas sociais, a Teoria Jurídica não pode ser conduzida de forma isolada: deve-se, antes de tudo, compreender a necessidade do diálogo entre os ramos do conhecimento. A literatura detém a capacidade de inaugurar uma nova perspectiva ao direito: a questão do existencial como elemento de humanização da ciência jurídica, por meio da perspectiva poética. A linguagem jurídica é, antes de tudo, linguagem, ambiente no

7 Mormente da segunda metade do século XX em diante, a tradicional abordagem dogmática foi cedendo espaço, ainda que paulatinamente, à zetética jurídica, na maior parte do mundo ocidental.

8 Comentários do Professor José Eduardo Faria, em entrevista concedida à $\mathrm{OAB} / \mathrm{SP}$, em maio de 2017. 
qual o ser humano está imerso. Entretanto, a estrutura independente da jurisdição enquanto manifestação do poder estatal soberano leva, ainda que não intencionalmente, ao distanciamento da realidade social cotidiana. Percebe-se que há a patente tentativa de se separar o direito do mundo real. Nesses termos, o universo jurídico seria o "mundo do dever-ser" e exprimiria um paradigma de "perfeição" a ser alcançado pelo mundo em que vivemos. Já a arte, por sua vez, não se vangloria; ela é "humilde”. A ela não se impõem limites dogmáticos: seu modelo zetético se traduz em pura liberdade para se questionar o que for que seja; a sua linguagem é capaz de dialogar com todos os ramos do conhecimento. Neste sentido, Pietrofonte (2002, p. 32) reverencia o papel da arte na linguagem:

\begin{abstract}
A arte tem a propriedade de, por meio das estratégias discursivas de que se vale, fazer complexificações que outros discursos não podem fazer. O discurso poético opera com figuras de linguagem [...]. Assim, objetivamente, o discurso poético revela a complexidade que existe entre os que fazem a lei e os que a sofrem.
\end{abstract}

O direito não deve esquivar-se do debate daquilo que lhe é inerente: a perspectiva pessoal do indivíduo. A reflexão do homem a respeito de sua própria existência e de suas relações interpessoais deve ser compreendida como impulso de criação (seja nas artes, na ciência ou na norma) e, portanto, como elemento integrante da gênese de tudo aquilo que regula e permeia a vida humana. Não se pretende aqui o retorno ao jusnaturalismo - aliás, não seria razoável ambicionar tal nível de discussão, na medida em que foge ao escopo deste estudo. Também não se propõe a busca de uma revelação essencialista da lei. Apenas propomos a adoção de outra perspectiva, sob um viés mais independente do racionalismo estritamente formalista da norma. O olhar do direito através da poética seria, assim, o salto desejado (até mesmo necessário) para a leitura mais aproximada da realidade.

O discurso jurídico é um sistema operativamente fechado e adstrito somente àqueles que se dedicam ao seu estudo. $\mathrm{O}$ ingresso nesse universo não é livre e desimpedido, na medida em que há uma série de dificuldades impostas aos que pretendem se "aventurar" nessas águas. O consequente distanciamento entre direito e realidade social implica a indesejável elitização do saber jurídico, por meio do "empoderamento" de seus operadores, em face daqueles que ficam à margem de uma linguagem 
praticamente inacessível aos "não-iniciados". Analisar o direito sob a ótica da poética é lidar com a sua realidade desnuda e abdicar do profetismo jurídico autolimitado na própria concepção. A própria separação entre as concepções de ser e dever-ser reflete a dificuldade do direito em enfrentar as mazelas cotidianas.

Historicamente, a Teoria do Direito se desenvolveu a partir do profetismo jurídico. Explica-se: profeta é o "indivíduo que prediz o futuro" (Aurélio, 2005, p. 667) - ou seja, aquele a quem não incumbe a análise da realidade, mas que aponta o futuro. Ao contrário disso, a poética tem a capacidade simbolizadora: ela se debruça na percepção do humano de forma livre, não estagnada no passado e sem a pretensão de previsões futuristas. Segundo Willis e Cantarini (2014, p. 41), "a ficção é a verdade do direito", e é exatamente a partir dessa ótica que "também se abre uma perspectiva para o desenvolvimento, em teoria da ciência jurídica, em sentido próprio e atual, isto é, falibilista, porque humana e, logo, 'possibilista', imaginária”. O que se pretende dizer com isso é que não existe perfeição em nenhum dos léxicos, pois onde há o humano também há a diversidade de olhares (e o direito se determina, em última análise, na coerência narrativa). A partir de Kafka, é possível traçar-se essa aproximação com o presente e com o humano. Ao ler-se o texto, percebe-se uma nítida identificação dos operadores do direito com as personagens e as situações elencadas na obra. Essa capacidade de aproximação é característica inerente à literatura, e por isso a sua utilização torna-se imprescindível à compreensão do direito.

\section{MITO, JUSTIÇA, IMAGINAÇÃO E UTOPIA}

O direito não se desenvolveu exclusivamente a partir de si mesmo; a organização que atualmente vislumbramos não existia nos atuais moldes, no princípio da normatização. Assim como em outros campos do saber, o direito esteve tradicionalmente ligado a concepções mitológicas (fato que é de conhecimento notório, em especial no que se refere às culturas da Grécia e de Roma, mas que se perpetuou ao longo de toda a tradição cristã). A lei, por muito tempo, fora concebida como fruto da vontade divina, que se impunha aos seus servos por meio da revelação. 
Neste capítulo, passamos a tratar da relação entre o mito, a imaginação e o direito, bem como da importância dessa discussão para fins de compreensão dos sistemas atuais.

\subsection{O MITO DA JUSTIÇA: UMA NECESSIDADE OU UM ENTRAVE AO DESENVOLVIMENTO DO DIREITO?}

Se reconhecemos a importância de se romper com o profetismo desempenhado ao longo da história jurídica, não é possível negar a importância do mito e da religiosidade para a compreensão do direito. O mito é a expressão, por meio de símbolos, do mundo e da realidade a partir de narrativas e representações coletivas. Tal expressão se manifesta por meio de histórias (contos, fábulas) em que deuses imbuídos de características humanas protagonizavam situações típicas da existência humana, tais como fecundação, nascimento, morte, união, separação, guerra, paz, natureza. Segundo Kierkegaard (2012, p. 50), "o mito faz com que se passe no exterior o que é interior". O mito desvenda o desejo humano em suas mais íntimas aspirações; trata-se de um olhar ficcional do mundo que desnuda a substância da existência humana. Paradoxalmente, podemos dizer que é na ficção que encontramos a realidade - qualidade do que é real, daquilo existente no universo físico -, concebida como "a consagração da sintonia entre a representação sensível do objeto (imagem) como a interpretação mental do mesmo (ideia do objeto)" (Ganda et al., 2016, p. 05).

É mítico o nascimento do direito. Vejamos a concepção da hermenêutica jurídica, cuja etimologia nos remete ao deus olímpico Hermes ('E $\rho \mu \eta \dot{s}$ ), filho de Zeus e Maia, mensageiro responsável por interpretar a vontade dos deuses.

Sob o nome de Têmis ou Diké, seja em Roma ou em Atenas, a justiça é paradoxal, ora se afasta, ora se aproxima. Não há concretude ou objetividade fixa, há uma variação em seu conteúdo ao longo da história. $\mathrm{O}$ direito é ficção - obra do desejo humano -, e o elemento mítico está inserido no seu ideal de justiça e nos ritos em que se funda9. Cite-se o conceito de justiça de Ulpiano, para quem é justo "dar a cada um o que é

9 Dessa forma, pode-se afirmar, em linhas gerais, que a justiça seria, para o direito, aquilo que a verdade é para a filosofia: trata-se de um valor de difícil conceituação, mas que ocupa a posição central do sistema. 
seu" (suum cuique tribuere) (Krueger et al.,1889, p. 29). Em virtude de tal concepção, a questão que se apresenta é: quem dirá o que é de cada um? Percebe-se que inexiste um conceito fechado e inalterável.

Ocorre que, não obstante a relativa indeterminação conceitual de justiça, é inegável a sua presença no humano, seja em maior ou menor intensidade. Vejamos o ocorrido na obra de Kafka, em que Josef K., cuja conduta se apresenta irrepreensível, é capturado pela espada da justiça sem ao menos saber o motivo. Não há o devido processo legal, publicidade ou qualquer outra garantia inerente ao Estado Democrático de Direito. Independentemente da corrente ou conceito adotado de justiça, certo é que qualquer pessoa saberá que K. sofreu uma injustiça (uma forte evidência de que a ideia tende muito mais ao subjetivismo do que à objetividade, o que será aprofundado no subtítulo 3.1 deste estudo).

Eduardo Galeano afirma que a utopia é responsável por fazer o homem caminhar, pois, na medida em que se caminha em direção ao horizonte, este se afasta (Portal Brasil, 2015). Ora, se a justiça é a utopia do direito, deve então ser entendida como necessária a sua marcha e a sua evolução. Contudo, se é verdade que "a diferença entre o remédio e o veneno reside na dose" ${ }^{10}$, igualmente o ideal de justiça não deve assumir a forma de crença ao ponto de se cegar e impedir o avanço do direito enquanto ciência. Talvez seja nessa paradoxal aproximação e afastamento de horizontes que o artífice do direito se reencontrará com o prazer da atividade jurídica. Assim como a imaginação concebida por Kierkegaard, a justiça deve ser equilibrada entre a fantasia e realidade, caminhando-se sobre a corda bamba da existência, mesmo ante a tentativa de se cientificála.

Por sua vez, o sentido de justiça tampouco deve obstaculizar o desenvolvimento do direito científico - como ramo da ontologia -, sob o risco de se promover excessivo subjetivismo, que fatalmente conduziria à arbitrariedade e falência do sistema jurídico. Para tanto, a ciência jurídica não deve prescindir da discussão técnica sobre o método de sua execução, ponto necessário para se validar a sua cientificidade perante o corpo social, além de imprescindível para se alargar a ultrapassada concepção de que o

10 Aforismo de Paracelso, médico e físico do século XVI. 
direito seria tão somente mera técnica de controle social (Guerra e Carnio, 2000, p. 105). Esse é, aliás, um dos grandes desafios contemporâneos do estudo da filosofia e da teoria geral do direito: nortear-se pela justiça, sem, contudo, mitigar a independência do direito como ciência autônoma.

\subsection{O poder judiciário, o mito da justiça e a paixão}

A dinâmica da 'coisificação' do humano demonstrada em $O$ processo revela um viés desapaixonado do direito, na medida em que este se promove como mero instrumento automatizado de controle social, autorreferenciado e totalmente despido de qualquer preocupação com o indivíduo que tenha tido a infelicidade de ser processado. Kierkegaard fala de uma época de aparências, despida de profundidade e coerência: "en La Época Presente la acción y la decisión son tan escasas como lo es el deleite del riesgo al nadar en aguas poco profundas" (Kierkegaard, 2012, p.45). O exercício do direito como mera aplicação técnica da norma é fruto da concepção moderna de sociedade. Tornou-se a atividade jurídica mecanizada e fria, despida de beleza e arte. Atualmente, o profissional da área, não por acaso chamado de operador do direito, por vezes exerce o seu labor como se estivesse em uma linha de produção industrial. Sabemos que a realidade prática desse microuniverso particular que se tornou a atividade jurídica demanda, dos profissionais do ramo, a adoção de uma produção “massificada”. No entanto, o excesso de processos ou o tempo exíguo não podem impossibilitar a discussão para possíveis soluções. É essencial que o jurista acolha a sutil inquietação que o tema provoca a fim de se promover o enfrentamento dessas questões, desde o âmbito da academia até o dos escritórios e gabinetes mais remotos. Para Kierkegaard, o processo de racionalização excessiva culminou na ruptura do homem com a sua religiosidade, ou seja, com o elemento mítico de sua própria existência, custando-lhe a perda da subjetividade. Esta, no sentido kierkegaardiano, está diretamente relacionada à paixão, como algo que arde, no sentido da palavra dinamarquesa inderlighed (interioridade) e que se refere à paixão e ao ardor - como "algo que é feito com profundo ânimo". Na medida em que se retira do homem a paixão, o direito igualmente perde seu sentido original - o que explica, ao menos em parte, o caos jurídico em que atualmente nos encontramos. O direito foi seduzido pelo utilitarismo 
puramente mercenário e abandonou seus ideais de outrora. Se, por um lado, o reflexionismo trouxe o avanço tecnológico, por outro, ele também massificou o indivíduo e esmagou a sua capacidade de se angustiar. É, portanto, necessário (re)pensar-se uma alternativa viável ao profissional do direito, para que se promova, na prática jurídica, o (re)encontro com a paixão há muito perdida, a fim de se resguardar o verdadeiro objeto de proteção do direito: o indivíduo.

A obra de Kafka denuncia as vaidades da justiça desde a Academia: "[...] K. olhou-o com curiosidade, era o primeiro estudante da desconhecida ciência do direito que ele de algum modo encontrava pessoalmente, um homem que um dia, com certeza, chegaria a altos cargos burocráticos” (2017, p. 73). A força que impele o referido estudante é o desejo de poder que o conhecimento promove frente ao homem comum. Na narrativa, ele comete inúmeros abusos em razão de seu status de conhecedor das leis e passa a assumir uma posição de superioridade frente às demais pessoas, simplesmente pelo cargo que um dia virá a ocupar. O juiz da instrução é como uma divindade em posição de sacralidade: alude Kafka sobre "o juiz de instrução estivesse a observá-lo do alto de uma janela, e soubesse portanto que ele viera à audiência.” (2009, p. 24), no qual se concentra o poder inquestionável. Interessante notar a perda da sensibilidade - e da subjetividade - dos funcionários do cartório, que "não levam o público em muita consideração" (2017, p. 81), o que lhes causa um sofrimento que passa desapercebido aos demais: "Talvez nenhum de nós seja duro de coração, gostaríamos talvez de ajudar a todos, mas como funcionários do tribunal damos facilmente a impressão de que somos empedernidos e não queremos ajudar ninguém. Sofro muito com isso" (2017, p. 91). Vale, no ponto, recordarmos os inúmeros casos de adoecimento a que chegam os servidores do Poder Judiciário, que, em alguns casos, terminam em suicídio, como de fato vem ocorrendo ao longo dos anos no Tribunal Regional do Trabalho de São Paulo11. O curso natural a que o sistema remete é a gradual institucionalização do indivíduo, mas perder a autorreferenciação enquanto indivíduo fatalmente levará ao adoecimento,

11 A revista Veja veiculou, em abril de 2016, que um suicídio ocorre a cada seis meses no prédio do TRT-SP, em sua maioria de funcionários do tribunal. Disponível em: < $\underline{\text { http://veja.abril.com.br/brasil/o-predio-do-trt-sp-um-suicidio-a-cada-seis-meses/>. }}$. Acesso em: 4 jun. 2017. 
conforme aponta Kafka (2017, p. 94): “[...] julgou perceber que eles, habituados ao ar do cartório, suportavam mal o ar relativamente fresco que vinha da escada". Josef $K$. se indigna com as condições dos cartórios que guardam os processos (2017, p. 77):

A escada de madeira não explicava nada, por mais que se olhasse para ela k. notou então um pequeno pedaço de papel ao lado do primeiro lance da escada, foi até lá e leu, escrito numa letra infantil e desajeitada: 'Acesso aos cartórios dos tribunais'. Aqui no sótão deste prédio de aluguel ficavam os cartórios?

Quando apontamos o descaso a que os servidores estão submetidos, a referência não se restringe tão somente às dependências, prédios e instrumentos de trabalho: há uma violência institucional que se reproduz e reverbera em todos os envolvidos no processo, desde as partes até os advogados, serventuários, promotores e magistrados. A atividade jurisdicional, não raramente, é insalubre e solitária. Esse cenário destrói a paixão a que deve se entregar o profissional do direito, justamente porque o sistema decide, diretamente, a vida das pessoas. É importante que se promova o enfrentamento dessas questões até mesmo na esfera da saúde pública.

Destacamos que, em meio a esse contexto, existem profissionais do direito que ainda resistem no exercício de sua atividade com a devida paixão pela justiça, a exemplo do desembargador do TJ-SP Pauma Bisson, que nos oferece uma verdadeira aula de humanidade por meio do acórdão registrado sob o $\mathrm{n}^{\mathrm{O}}$ 1001412- $\mathrm{o} / \mathrm{o}$ :

[...] É uma plaina manual feita por ele em pau-brasil, e que, aparentemente enfeitando o meu gabinete de trabalho, a rigor diuturnamente avisa quem sou, de onde vim e com que cuidado extremo, cuidado de artesão marceneiro, devo tratar as pessoas que me vêm a julgamento disfarçados de autos processuais, tantos são os que nestes vêem apenas papel repetido [...] (grifo dos autores).

Assim, a discussão desses problemas se demonstra imprescindível desde a Academia até os órgãos públicos, na medida em que a paixão define, em última análise, o próprio ser humano. 


\section{O DIREITO E A JUSTIÇA: UM FENÔMENO SOCIAL}

\subsection{Do conceito jurídico de justiça - menor estabilidade do que se aparenta}

A análise do conceito de justiça e das instituições jurídicas erigidas a tal propósito diz muito sobre uma sociedade. Na grande maioria das nações (na medida em que a maior parte dos sistemas nacionais tem constituições escritas), os desejos e aspirações da coletividade estão estampados na Constituição, segundo a sua cultura e a ideologia adotadas em determinada época de sua existência política. Mesmo quando se trata de uma sociedade cuja constituição seja histórica (não codificada), a análise de sua estrutura jurídica frequentemente evidencia os seus valores primordiais, além de, por vezes, poder-se extrair a interpretação adotada acerca destes. É algo semelhante a uma "impressão digital": as instituições jurídico-políticas demonstram claramente o "dever-ser" adotado pelo sistema, e, por meio da análise sobre aquilo que a coletividade "desejaria ser", alcançamos, paradoxalmente, a compreensão sobre "aquilo que a sociedade não é”.

Preliminarmente, conforme já mencionamos no $3^{\mathrm{o}}$ parágrafo do subtítulo 2.1, qualquer tentativa de conceitualização sobre o valor justiça será inevitavelmente carregada de imensa subjetividade. Deve-se ter em mente que a compreensão acerca dessa ideia difere em todas as culturas (o que não é de se espantar, considerando-se que o conceito adota diferentes interpretações no próprio campo individual, variando de pessoa a pessoa). $\mathrm{Na}$ medida em que a construção social das coletividades está sujeita a outros elementos basilares (tais como costumes, história, mitologia e religião, dos quais extraem seus valores), torna-se impossível separar a noção de justiça sem que, preliminarmente, seja analisado o contexto no qual esteja inserida.

Por muito tempo, a ideia de justiça esteve vinculada à ideia de virtude, socialmente relacionada à necessidade de harmonia social alcançada mediante o respeito às leis estabelecidas. Aristóteles, em Ética a Nicômaco, fala sobre o tema em diversas passagens:

Como vimos que o homem sem lei é injusto e o respeitador da lei é justo, evidentemente todos os atos legítimos são, em certo sentido, atos justos; porque os atos prescritos pela arte do legislador são legítimos, e cada um deles, dizemos nós, é justo (2003, p. 79) 
O citado filósofo continua: "Por essa mesma razão se diz que somente a justiça, entre todas as virtudes, é o 'bem de outro', visto que se relaciona com o nosso próximo" (2003, p. 80), e, "Portanto, a justiça neste sentido não é uma parte da virtude, mas a virtude inteira; nem é seu contrário, a injustiça, uma parte do vício, mas o vício inteiro" (2003, p. 80). Assim, a concepção de justiça como o "meio-termo" a ser alcançado, residindo na prudência a maior virtude do homem e qualificada pela habitualidade de suas boas ações, denota a ideia daquilo que é justo como a prática habitual da virtude e do respeito às leis.

Contudo, a ideia de justiça tal como um "comando divino" que se impõe à sociedade, determinando a necessidade de obediência a preceitos contidos em um sistema religioso, tem sido, majoritariamente, ao longo da história humana, a ideia preponderante. O conceito segundo o qual "justo é aquilo que vem de Deus" - conforme uma teoria que veio, modernamente, a ser conhecida como a Teoria do Comando Divino - tem sido a principal bússola jurídica e moral desde os primórdios e, ainda hoje, é amplamente aplicada em grande parte das culturas existentes. No mundo ocidental, boa parte dessa ideia caiu em desuso desde a separação entre religião e Estado, uma divisão positivamente promovida pelo movimento iluminista iniciado no século XVII. Entretanto, a convivência supranacional com povos que, por outro lado, adotam a Sharia (Lei Islâmica) como base jurídica para suas respectivas organizações político-sociais tem se tornado um dos maiores desafios à integração cultural.

Fato é que um sistema jurídico vinculado a qualquer sorte de escrituras sagradas das quais se extraiam preceitos de natureza cogente causa enorme insegurança jurídica, até mesmo entre os povos que adotam essa espécie de organização. O Alcorão, assim como a Bíblia crista ou a Torá judaica, são textos religiosos cujas origens remontam ao início das civilizações (ou seja, são produtos de determinado momento histórico), e, frequentemente, suas determinações são compreensíveis apenas se considerarmos o contexto em que foram concebidas. Como a grande maioria de seus preceitos é transmitida por meio de parábolas, a interpretação daquilo que é considerado (ou não) justo e legítimo fica ao exclusivo arbítrio do intérprete. Ou seja, o sistema acaba por se fundamentar, em última análise, em puro subjetivismo. 
Isso talvez não fosse um problema tão grande, caso culturas tão diversas como a islâmica e a cristã não tivessem escalas tão distintas em sua hierarquia de valores. No ponto, cabe uma explicação: pode-se afirmar, com alto grau de certeza, que todas as culturas ostentam os mesmos valores, pelo simples fato de se tratarem de organizações humanas. Seres humanos, por sua vez, valorizam aquilo que lhes é benéfico e que, de uma forma ou de outra, lhes auxilie em sua sobrevivência. Essa é a razão pelo qual o assassinato (tirar a vida de outro ser humano sem justificativa plausível) é, em todas as culturas, um evento socialmente criminalizado e punido. $\mathrm{O}$ mesmo ocorre em relação à proteção do patrimônio (furto, roubo), assim como na proteção conferida a instituições milenares como o casamento. $\mathrm{O}$ que se difere, em todos esses casos, não é somente a forma pela qual cada cultura lida com tais questões - normalmente, em nuances relacionados com a amplitude do instituto ou a aplicação da penalidade, quando da violação da norma -, mas, sim, a escala de valores envolvidos. Isso apenas se torna evidente ao contrapormos e compararmos, analiticamente, a escala de valores de duas culturas diferentes. Tomemos por base o direito à vida, por exemplo: valor que, para a cultura ocidental de tradição europeia, se erige como o mais sagrado instituto sociocultural, contra a qual nenhum outro, em circunstâncias normais, consegue preponderar ${ }^{12}$. Ao contrapormos a cultura japonesa, por outro lado, pode-se verificar que, apesar de sua longa história, apenas muito recentemente (mais precisamente após a segunda guerra mundial), o direito à vida passou a se sobrepor à noção de dever (outro conceito extremamente subjetivo, cuja compreensão somente pode ser extraída casuisticamente). Nesses termos, e considerando o fato de que muito já discorremos neste estudo sobre o íntimo liame existente entre direito e literatura, é interessante invocarmos um trecho do livro Hagakure (um dos últimos genuínos relatos escritos sobre o código guerreiro samurai, escrito por Tsunetomo Yamamoto, durante a transição do Japão feudal à modernidade). Segundo o relato, o servo pessoal de Fukahori Magokoru, segundo filho do lorde Kanzaemon,

12 A questão do aborto, como poderia ser suscitada neste ponto, não é algo diretamente relacionado ao valor da vida em si, mas com o que se entende por "ser vivo" e a determinação do momento no qual este passa a existir. Já a questão da eutanásia inserese, justamente, nas poucas ocasiões em que a qualidade da sobrevivência impera sobre a própria vida em si - ou seja, uma circunstância anormal. 
confundindo seu mestre com um javali durante uma caçada na floresta, dispara seu rifle contra o joelho de seu amo, que imediatamente cai ferido, de uma altura considerável. A primeira reação do servo, quando percebera o ocorrido, fora a intenção de cometer o seppuku (suicídio tradicional japonês), ao que Magokoru interveio: "você pode abrir seu estômago depois, mas agora não estou me sentindo bem, traga-me um pouco de água" (Yamamoto apud Lapo, 2005, p. 132). Acalmados os ânimos, o servo iria retomar o seu dever - cometer o seppuku -, mas seu amo interveio novamente. Voltando para casa, Magokoru pediu ao pai que perdoasse seu servo, o que de fato veio a ocorrer: "foi um engano, não se preocupe. Volte ao trabalho" ${ }^{13}$. Esse mesmo espírito de dever, que se sobrepunha à vida humana com frequência assombrosa, era a motivação para os ataques kamikazes conduzidos ao longo de toda a Segunda Guerra, muito embora a era de ouro dos samurais já houvesse, há muito, deixado de existir. Para eles, valores milenares sobrepunham a noção do dever aos demais direitos, da mesma forma que a Jihad islâmica (dentro de seu conceito de "guerra santa”) tradicionalmente enaltece o ataque suicida em detrimento da vida do indivíduo que o pratica.

Então, à elucidação do exposto, como podemos supor que o valor "justiça" esteja apto a ser utilizado como paradigma comportamental que fundamente a vida em sociedade, mormente quando sua conceituação é tão subjetiva a ponto de criar divisões tão abissais entre culturas que deveriam, ao menos supostamente, coexistir?

Bem, este é justamente o problema: para muitas religiões, a depender da interpretação adotada, simplesmente não deve haver coexistência. Daí a razão pela qual a adoção de um sistema jurídico que extrai seus valores da religião, qualquer que esta seja, somente encontrará seu caminho por meio da imposição (leia-se: "guerra") da vontade alheia. Se, no bojo dos sistemas democráticos, concebemos a justiça como fundamento de nossa ordem social, mediante a sujeição das vontades pessoais sob o domínio soberano do bem-estar coletivo - pressuposto necessário e inafastável da coexistência entre os mais diversos indivíduos -, para outros sistemas, a justiça é um

13 O manuscrito original há muito se perdeu. Também conhecido como o Livro dos kamikases, pouquíssimas cópias sobreviveram após a Segunda Guerra, na medida em que as forças de ocupação ordenaram a sua destruição. Atualmente existem quatro transcrições do texto original, em japonês, que pouco diferem uma da outra. 
dever divinamente emanado, que não tolera posições divergentes, quer internamente (dentro do próprio corpo social) quer externamente (perante outras culturas e seus respectivos sistemas jurídicos).

Assim, não é de se surpreender que tal concepção de justiça torne-se predatória segundo a sua própria unilateralidade. Não que o exemplo anteriormente evocado da cultura japonesa (cuja noção de justiça não está tão intimamente atrelada à religião) fosse muito diferente da islâmica em termos de dominação: sua escala de valores só sofreu alterações (e, ainda assim, somente em tempos mais recentes) porque eles perderam a guerra, dentro de um embate que inevitavelmente viria a ocorrer, cedo ou tarde, entre duas culturas igualmente poderosas e soberanas.

Conclui-se, portanto, que a adoção do termo justiça, cuja valoração depende de um juízo extremamente subjetivo que se submete aos conceitos mais diversos - a depender da cultura, da religião e do momento histórico de dada sociedade -, não pode servir de paradigma para erigir instituições sociais cujo funcionamento dependa de valores outros extraídos de sistemas não-jurídicos.

\subsection{Do conceito popular de justiça: o papel do sistema jurídico em regimes totalitários}

A literatura e o direito são abstrações humanas idealizadas e concebidas para guiar o comportamento humano - aquele, pela consciência; este, pela coerção. Seja como for, ambos têm o condão de induzir a comportamentos. Dito isso, este artigo propõe-se a analisar, segundo perspectiva eminentemente literária (e, em especial, sob a ótica de Kafka), a mutabilidade das concepções de justiça e de direito que se operam a partir dos anseios humanos.

O direito tem sido frequentemente utilizado, ao longo dos tempos, como instrumento de controle social, justificando-se por meio dele as mais terríveis barbáries. Conforme já abordamos no início deste trabalho, Josef K. questiona o Estado de Direito; ou seja, a normalidade do cumprimento da lei. Quando ocorre a ruptura da tradição jurídica de um país democrático com o princípio da razoabilidade, o Estado de Direito se vê ameaçado pela tirania. Segundo Abbagnano (2007, p. 963), totalitarismo é a "prática do Estado totalitário, vale dizer, do Estado que que pretende identificar-se com a vida dos seus cidadãos. Esse termo foi cunhado para designar o fascismo 
italiano e o nazismo alemão”. O desenvolvimento dos regimes totalitários ocorreu principalmente após a Primeira Guerra Mundial, quando se instaurou uma crise política e econômica mundial sem precedentes, o cenário perfeito para o surgimento de um "messias" político, centralizado na figura de uma pessoa capacitada para "salvar" a nação. Foi assim com o nazismo e o stalinismo, além de outros regimes semelhantes que despontaram ao longo do território europeu. Fenômeno igual também ocorreu no oriente, a exemplo do Japão militarizado após a era Meiji (1888 a 1912), da china Maoísta e do Khmer Vermelho de Pol Pot no Camboja, apenas para citar alguns.

São características do Estado totalitário o uso excessivo de força militar como forma de reprimir qualquer tipo de oposição ao governo; ausência ou manipulação de eleições; censura e controle dos meios de comunicação por partido único e a propaganda governamental para promoção da figura do líder. Outro traço peculiar desses regimes é o abuso da expedição de decretos por parte do Poder Executivo, ante à fragilidade do Legislativo. Pode-se afirmar, ainda, que existe totalitarismo independentemente de orientação ideológica, seja essa eminentemente progressista ("de esquerda") ou conservadora (“de direita”): uma com foco na ideologia comunista e em defesa da extinção da propriedade privada, a outra marcada por uma filosofia fundamentada, ao menos supostamente, em ideais liberais. Seja como for, ambas carregam forte discurso ético: a primeira, pautada pela igualdade; a segunda, orientada pela proteção à propriedade. Fato é que em ambas há a dilatação exacerbada do Estado, acompanhada da consequente redução do cidadão enquanto indivíduo. Observa-se a sistemática supressão da subjetividade, em detrimento do crescimento de uma massa manipulada por meio da força.

O discurso totalitário geralmente é um discurso que mescla nacionalismo ao discurso religioso, tal como aqueles proferidos durante os famosos comícios públicos de Adolf Hitler, e vem sempre acompanhado pela supressão de direitos e do crescimento do poderio estatal. Vale lembrar o pensamento de Carl Schmitt, cuja concepção estatista "negava as garantias dos direitos individuais do paradigma liberal, entendendo que o Estado, ao estabelecer o direito por meio de seu soberano, não pode admitir a autonomia individual dos cidadãos” (Alves e Oliveira, 2012, p. 232). 
Schmitt não somente defendeu o regime nazista, mas, como jurista, formulou uma vasta teoria em defesa do uso da força e da adoção de uma política de "conveniência unilateralizada" com o propósito de promover a autoridade suprema do Estado. Para o autor, a guerra que visa a combater o inimigo não seria um estado de exceção, e se necessário fosse, seria possível (e até mesmo desejável) suspender o direito, a fim de se resguardar a soberania.

Na Itália destacou-se Mussolini, líder socialista que fundou, em 1919 o fasci di combattimento (esquadrões de combate), composto por excombatentes e desempregados. O país também experimentava uma profunda crise econômica e política, com picos de inflação incontrolável e governo fragilizado pelos movimentos sociais - um solo propício ao desenvolvimento do fascismo, que acabou por perseguir e matar milhares de pessoas em nome da segurança do Estado. Como se verifica, o direito frequentemente serve de instrumento para a consecução dos objetivos políticos de regimes, sejam esses democráticos ou totalitários. A ocorrência de tal fenômeno não causa espanto; afinal, o direito é fruto do desejo humano, e este, não raramente, norteia-se pela sede de poder, independentemente de encontrar guarida em alguma espécie de fundamento, no qual se possa conferir aparência de legitimidade ao regime.

De toda sorte, ao analisarmos a história dos povos, percebe-se como a obra de Franz Kafka, mais de cem anos depois, ainda é assombrosamente contemporânea, na medida em que o modelo jurídico descrito em $O$ processo reproduz, com precisão espantável, as mazelas ainda hoje vivenciadas nos mais diversos tribunais brasileiros. Outrossim, a advertência extraída de sua literatura, que aponta os perigos advindos de um sistema jurídico autorreferenciado e indiferente à realidade social, é uma questão igualmente atual, na medida em que o poder judiciário, de tempos em tempos - com frequência muito maior do que gostaríamos de admitir - perde a sua independência para se tornar simples instrumento político, mero prolongamento do poder executivo assumido por governos transitórios, na consecução de objetivos igualmente ocasionais ${ }^{14}$-, se é que se possa dizer que exista qualquer objetivo que seja, em um sistema judicial

14 Fenômeno este que se traduz, a grosso modo, no mundo jurídico brasileiro, como "ativismo judicial". 
semelhante àquele descrito por Kafka. Seja como for, em todos os casos apontados, o sistema derradeiramente acaba por relegar o indivíduo ao último plano, justamente quando este deveria ser, em todos os casos, o principal objeto de proteção do sistema (que, aliás, é a única razão pela qual se justifica a própria existência das instituições jurídicas).

\section{O DIREITO AO ESQUECIMENTO: É POSSÍVEL RECOMEÇAR?}

\subsection{A publicidade dos atos processuais e o esquecimento}

A literatura de Franz Kafka, além de nos demostrar os horrores do processo judicial mal conduzido sob os auspícios de um sistema estatal altamente burocrático e ineficiente, leva-nos ainda a uma derradeira questão: considerando-se que o processo judicial é, via de regra, público (ao menos nos regimes democráticos) e acessível a todos e considerando-se que o direito à informação tem estatura constitucional alçada à condição de garantia fundamental, questiona-se aqui um ponto em especial: um réu, independente de ser efetivamente culpado ou condenado pelo motivo que for, teria direito ao "esquecimento social" do processo que lhe julgou? A garantia à informação e à publicidade dos atos públicos pode sobrepor-se irrestritamente aos direitos fundamentais da intimidade, da vida privada e da honra, justificando a mácula perpétua que causa um processo judicial na vida de um indivíduo (ainda que existam institutos jurídicos como o dano moral)?

O direito ao esquecimento, também conhecido como o 'direito de ser deixado em paz', é a prerrogativa que uma pessoa possui de não se permitir que um fato - criminoso ou não, e ainda que verídico - ocorrido em algum momento de sua vida, seja exposto ao público, causando-lhe sofrimento. Um dos eventos mais emblemáticos sobre o tema foi o "caso Lebach" (Soldatenmord von Lebach), conduzido pelo Tribunal Constitucional Alemão, em que três homens foram condenados pela morte de quatro soldados alemães em 1969, na cidade de Lebach. Após o cumprimento da pena e prestes a sair da prisão, um dos homens soube que a imprensa veicularia fotos dos condenados em um programa de televisão e ajuizou uma ação inibitória. O Tribunal Constitucional Alemão decidiu que a imprensa não poderia explorar o fato por tempo indeterminado, dada a proteção constitucional da pessoa do criminoso e de sua vida privada. 
Interessante é verificar que esse caso, cujo cerne trata justamente do direito ao esquecimento, jamais será esquecido.

A questão que se invoca, aqui, é se realmente pode ser possível o direito ao esquecimento numa sociedade com síndrome hipertimésica ${ }^{15}$. Talvez o sistema não queira, de fato, "esquecer", e o condenado ficará perpetuamente em dívida com a sociedade. Exemplo notório é o caso do exjogador de futebol Bruno, então goleiro do Flamengo, condenado por matar a modelo paranaense Eliza Samudio. Contratado pelo time de futebol Boa Sorte em março de 2017, os patrocinadores prontamente exigiram a demissão do goleiro, e o website do time foi hackeado em protesto à contratação. Eis aqui o claro modelo de uma sociedade que jamais esquece, por mais democrática que se considere.

Tal fenômeno, aliás, é bem conhecido há milênios pelos povos orientais: sua existência histórica, registrada em diversas passagens da literatura japonesa, evidencia-se no fato de a pena do delito alcançar não apenas o condenado, mas toda a família, ao longo de diversas gerações. Embora o Japão tenha abandonado tal prática apenas há algumas décadas (mais precisamente após o término da Segunda Guerra Mundial), a Coreia do Norte, por sua vez, ainda promove a condenação coletiva de famílias inteiras, por delitos tão simples quanto "dormir na presença do grande líder" - este, aliás, é crime capital executado por fuzilamento ${ }^{16}$. Basta que um único integrante da família cometa um crime para que a brutal "regra das três gerações" seja aplicada: se um indivíduo é considerado culpado pelo sistema e é enviado a um campo de concentração (sim, eles ainda existem), o mesmo destino terá toda a sua família, além das duas gerações subsequentes que lá nascerão, assim permanecendo por toda a vida (The Telegraph, 2017).

15 Segundo a descrição, trata-se de uma "condição na qual o indivíduo apresenta uma altíssima capacidade de memória autobiográfica”, caracterizando-se por uma memória episódica sobredimensionada. Em outras palavras, o indivíduo é incapaz de esquecer quaisquer eventos ocorridos em sua vida. Disponível em: <https://prezi.com/jhogz7yepfiw/sindrome-hipertimesica/>. Acesso em: 4 jun. 2017.

16 Em 30 de abril de 2015, o Ministro da Defesa da Coreia do Norte foi executado com um tiro de bateria antiaérea em frente a centenas de pessoas, por ter demonstrado "deslealdade ao presidente". Disponível em: $<$ http://www.bbc.com/portuguese/noticias/2015/05/150513 coreiadonorte execucao h $\underline{b}>$. Acesso em: 13 out. 2017. 


\subsection{A privacidade nos dias atuais: é possível esquecer?}

Esquecer é tão importante quanto lembrar. Mas, como é possível apagar os rastros das tramas vivenciadas numa era que aprisionou o humano nas redes sociais? Como é possível empreender uma nova trajetória ante a mitigação da privacidade? Vivemos em tempos líquidos, em que os valores se dissipam facilmente. A vida tornou-se pública, e não há mais reservas. Diante disso, é possível àquele que cometeu o delito não ser lembrado? Em uma era em que a mídia torna-se o maior dos tribunais, é realmente possível acreditar na ressocialização a que se propõe, ao menos na aparência, o sistema penal brasileiro?

Exemplo recente do não esquecimento foi veiculado pela mídia brasileira. Andreas von Richtofen ficou conhecido pelo crime cometido por sua irmã, Suzane Von Richtofen, que, juntamente com o namorado, em 2002, assassinou seus pais $(\mathrm{G} 1,2017)$. Mesmo após concluir bacharelado em Farmácia e Bioquímica e se doutorar em Química na Universidade de São Paulo, Andreas é referido tão somente como o 'irmão de Suzane'. Aliás, ele foi recentemente encontrado num bairro da zona sul de São Paulo, em suposto surto psicótico, e veio a ser internado na ala psiquiátrica de um hospital público. Toda a família Richtofen provavelmente será sempre lembrada pelo crime de uma única integrante (Suzane). Vale lembrar que, quando da progressão ao regime semiaberto, em 2014, temendo retaliações por parte da população e ampla cobertura da mídia, Suzane recusou-se deixar a penitenciária. Há, inclusive, a expectativa do lançamento de filme sobre a sua vida. A respeito do direito ao esquecimento, François Ost (2005, p.160) alerta:

Uma vez que, personagem pública ou não, fomos lançados diante da cena e colocados sob os projetores da atualidade - muitas vezes, é preciso dizer, uma atualidade penal -, temos o direito, depois de determinado tempo, de sermos deixados em paz e a recair no esquecimento e no anonimato, do qual jamais queríamos ter saído.

Então, pode-se dizer que os casos com maior exposição midiática tendem a jamais serem esquecidos. Por outro lado, a Constituição Brasileira assegura o direito à vida privada (privacidade), à intimidade e à honra (art. $\left.5^{\circ}, \mathrm{X}\right)$. Afirma-se, inclusive, que o direito ao esquecimento é uma decorrência da dignidade da pessoa humana (art. $1^{\circ}$, III, da CF/88). De fato, há uma evidente contradição entre o mundo "real" e o do "dever-ser", 
fato esse que precisa ser discutido e repensado, pois, em última análise, a liberdade de um indivíduo não deve violar a liberdade de outrem.

\section{CONSIDERAÇÕES FINAIS}

Em termos metodológicos, entende-se que toda e qualquer área da ciência, a fim de ser alçada à categoria de ramo autônomo, deve ser capaz de evidenciar seu fundamento por meio de suas próprias ferramentas - ou seja, sem ter de recorrer a instrumentos externos. As ciências jurídicas não fogem à regra. Entretanto, o direito não pode deixar de dialogar com outros ramos do conhecimento; é necessário que o operador ostente a paixão inerente ao espírito humano, para poder desempenhar o fim social que o ofício demanda. Para tanto, é importante possuir uma mente aberta: deve-se permitir o vislumbre do direto segundo a ótica de Kafka, cuja literatura aponta para o perigo de se incorrer em uma justiça burocrática e ineficiente (efeito colateral perverso dos princípios da impessoalidade e da igualdade). Muito além do que apenas criticar o sistema jurídico por seus defeitos, trata-se de (re)pensar a estrutura a partir de suas deficiências, na medida em que o direito, como construção social que é, reflete, em última análise, a imperfeição da própria condição humana. Todo homem é um universo em si mesmo, e assim deve ser considerado pelo sistema antes da adoção de qualquer medida decisória. Considerando-se a perpetuidade das informações em tempos de internet e a assombrosa capilaridade das redes sociais ${ }^{17}$, deve-se ter em mente que o processo implica uma série de consequências que transcendem a mera esfera jurídica dos acusados, pessoas comuns cujas vidas serão irremediavelmente marcadas pela mácula de um registro permanente que, certamente, os condenarão a sofrimentos perpétuos.

Assim, torna-se essencial promover a reflexão acerca dos valores que, tradicionalmente, tem norteado os mais diversos ordenamentos jurídicos, de forma a (re)humanizar o senso comum de justiça.

Apenas o olhar apaixonado sobre a atividade jurídica é capaz de reinterpretar conceitos e reorientar as instituições, mas, para que isso ocorra, há de se enfrentar o debate com a coragem necessária para centralizar o sistema no sujeito, e não mais no processo judicial.

17 Não nos olvidando, também, do papel (ainda) desempenhado pelos canais tradicionais de mídia. 


\section{REFERÊNCIAS}

ABbagnano, Nicola. Dicionário de filosofia. Trad. de Ivone Castilho Benedeti. São Paulo: Martins Fontes, 2007.

ALVES, Adamo; OLIVEIRA, Marcelo. Carl Schmitt, um teórico da exceção num estado de exceção. Revista Brasileira de Estudos Políticos, v. 105, p. 225-276, 2012. Disponível em: <http://www.pos.direito.ufmg.br/rbep/index.php/rbep/article/view/P.o0 34-7191.2012v105p225/187 >. Acesso em: 10 nov. 2017.

ARISTÓTELES. Ética a Nicômaco. São Paulo: Martin Claret, 2003.

AURÉLIO. Dicionário da língua portuguesa. 6. ed. Curitiba: Positivo, 2005 .

BRASIL. Tribunal de Justiça do Estado de São Paulo. Agravo de Instrumento $\mathrm{n}^{\mathrm{o}}$. 1001412- $\mathrm{O} / \mathrm{O}$, Agravante: Isaias Gilberto Rodrigues Garcia. Agravado: Rodrigo da Silva Messias. 36 ${ }^{\mathrm{a}}$ Câmara (Ext. ${ }^{\circ} \mathrm{TAC}$ ). Relator Palma Bisson, Marília, 19 jan. 2006. Disponível em: <https://www.conjur.com.br/2011-jun-24/desembargador-deixaformalidade-lado-vota-marceneiro >. Acesso em: 10 nov. 2017.

BUENO, Roberto. $O$ papel da literatura na reconstrução das subjetividades. Marília: Em Tempo, v. 10, 2011.

CUNHA, Paulo F. Anti-Leviatã: direito, política e sagrado. Porto Alegre: SAFE, 2005 .

G1. 2017. Irmão de Suzane von Richthofen é internado em ala psiquiátrica de hospital em SP. Disponível em: <http://g1.globo.com/saopaulo/noticia/irmao-de-suzane-von-richthofen-e-internado-em-alapsiquiatrica-de-hospital-em-sp.ghtml>. Acesso em: 01 jun. 2017.

GANDA, Claudio; SAYEG, Ricardo; GUERRA FILHO, Willis S. (Org.). Estudos do imaginário jurídico. Rio de Janeiro: Lumen Juris, 2016. v. 1.

GUERRA FILHO, Willis S.; CARNIO, Henrique G. Teoria da ciência jurídica. São Paulo: Saraiva, 2000

GUERRA FILHO, Willis S; CANTARINI, Paola. Teoria poética do direito. Rio de Janeiro: Lumen Juris, 2014.

KAFKA, Franz. O processo. Trad. de Marcelo Backes. Porto Alegre: L\&PM, 2007.

KAFKA, Franz. O processo. Trad. de Modesto Carone. São Paulo: Companhia das Letras, 2017.

KIERKEGAARD, Sören A. La época presente. Trad. de Manfred Svensson. Madrid: Mínima Trotta, 2012.

KRUEGER， Paul; MOMMSEN， Theodor; SCHOELL， Rudolf; KROLL, Wilhelm. Corpus juris civilis. Berlim: Weidmann, 1889. Disponível em:

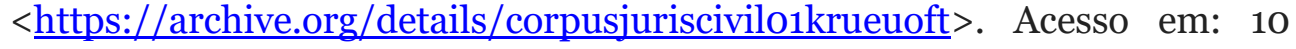
nov. 2017.

LAKATOS, Eva; MARCONI, Maria. Fundamentos da metodologia científica. 5. ed. São Paulo: Editora Atlas, 2003. 
OST, François. O tempo do direito. Trad. de Élcio Fernandes. Bauru: Edusc, 2005.

OST, François. El reflejo del derecho en la literatura. Doxa: Cuadernos de la Filosofía del Derecho, Alicante, v. 29, 2006, p. 334-348.

PIETROFONTE, Antônio. O discurso jurídico através do discurso poético. Em Tempo, Marília, n. 4, 2002, p. 24-33.

PORTAL BRASIL. 2015. Dilma lamenta morte de Galeano: "continuamos caminhando com os olhos no horizonte, na nossa utopia". Disponível em: $<$ http://www.brasil.gov.br/governo/2015/o4/dilma-lamenta-morte-degaleano-continuamos-caminhando-com-os-olhos-no-horizonte-na-nossautopia201d >. Acesso em: 10 nov. 2017.

TELEGRAPH, THE. 20 incredible things you didn't know about North Korea. Disponível em: <http://www.telegraph.co.uk/travel/destinations/asia/northkorea/galleries/what-you-didn-t-know-about-north-korea/there-s-a-threegenerations-of-punishment-rule/> . Acesso em: 13 out. 2017.

YAMAMOTO, Tsunetomo. Hagakure: Book of the Samurai. 2. ed. 2005. Disponível em: <https://archive.org/stream/pdfyW91d RoynCCibBAf/Hagakure\%20[Book\%20Of\%20The\%20Samurai]\#pa ge/n137/mode/2up >. Acesso em: 6 nov. 2017.

Idioma original: Português

Recebido: 20/06/17

Aceito: 09/10/17 